\title{
The phytopathogen 'Candidatus Phytoplasma mali' alters apple tree phloem composition and affects oviposition behavior of its vector Cacopsylla picta
}

\author{
Louisa Maria Görg ${ }^{1}\left[\right.$ ] Jannicke Gallinger ${ }^{1}\left[\right.$ Jürgen $_{\text {Gross }}^{1}[\mathbb{C}$
}

Received: 19 June 2020 / Accepted: 17 September 2020 / Published online: 26 September 2020

(c) The Author(s) 2020

\begin{abstract}
Apple proliferation disease is caused by the phloem-dwelling bacterium 'Candidatus Phytoplasma mali', inducing morphological changes in its host plant apple, such as witches' broom formation. Furthermore, it triggers physiological alterations like emission of volatile organic compounds or phytohormone levels in the plant. In our study, we assessed phytoplasmainduced changes in the phloem by sampling phloem sap from infected and non-infected apple plants. In infected plants, the soluble sugar content increased and the composition of phloem metabolites differed significantly between non-infected and infected plants. Sugar and sugar alcohol levels increased in diseased plants, while organic and amino acid content remained constant. As ' $\mathrm{Ca}$. P. mali' is vectored by the phloem-feeding insect Cacopsylla picta (Foerster, 1848), we assessed whether the insect-plant interaction was affected by ' $\mathrm{Ca}$. P. mali' infection of the common host plant Malus domestica Borkh. Binary-choice oviposition bioassays between infected and non-infected apple leaves revealed $C$. picta's preference for noninfected leaves. It is assumed and discussed that the changes in vector behavior are attributable to plant-mediated effects of the phytoplasma infection.
\end{abstract}

Keywords Apple proliferation disease $\cdot$ Binary-choice oviposition bioassay $\cdot$ Malic acid $\cdot$ Malus domestica $\cdot$ Multitrophic interactions $\cdot$ Sorbitol $\cdot$ Sucrose

\section{Introduction}

Most phloem-limited plant pathogens, such as viruses and bacteria (e.g., Candidatus Liberibacter, $\mathrm{Ca}$. Phytoplasma) are dependent on insect vectors for plant-to-plant transmission (Orlovskis et al. 2015). Some of them are able to directly or indirectly affect both plant (e.g., nutritional profile, chemical signaling) and vector insect (e.g., behavior, longevity, fecundity) (Bendix and Lewis 2018; Dermastia

Communicated by Marko Rohlfs.

Electronic supplementary material The online version of this article (https://doi.org/10.1007/s00049-020-00326-0) contains supplementary material, which is available to authorized users.

Jürgen Gross

juergen.gross@julius-kuehn.de

1 Laboratory of Applied Chemical Ecology, Institute for Plant Protection in Fruit Crops and Viticulture, Julius KühnInstitut, Federal Research Institute for Cultivated Plants, Schwabenheimer Str. 101, 69221 Dossenheim, Germany
2019; Eigenbrode et al. 2018; Galdeano et al. 2020; Gross 2016; Mauck et al. 2016; Perilla-Henao and Casteel 2016; Shikano et al. 2017; Stout et al. 2006; Tamborindeguy et al. 2017). While many research results on ecological interactions of plant viruses or $\mathrm{Ca}$. Liberibacter are available, many aspects of the interaction of $\mathrm{Ca}$. Phytoplasma, their vector insects and the role of plant metabolites mediating these interactions remain poorly understood for most systems.

The provisional genus 'Candidatus Phytoplasma' (Firmicutes: Mollicutes) (formerly known as mycoplasma-like organisms) combines obligate biotrophic prokaryotes characterized by the lack of a cell wall as well as a reduced genome (IRPCM Phytoplasma/Spiroplasma Working Team-Phytoplasma Taxonomy Group 2004; Oshima et al. 2004). So far, these Mollicutes can only survive endocellularly in plant phloem or different tissues of vector insects (Lee et al. 2000). Among the 'AP phytoplasma group' (Seemüller et al. 1998) or more specific, the $16 \mathrm{SrX}$ group (Lee et al. 2000), are several closely related phytoplasmas of economic importance as these phytopathogenic bacteria 
cause damage to fruit crops, such as apple and pear (Seemüller and Schneider 2004).

In apple trees Malus domestica Borkh., the phytoplasma 'Candidatus Phytoplasma mali' can provoke immense yield losses by causing apple proliferation disease. Losses of up to $€ 100$ million were recorded at an apple proliferation disease outbreak in Italy in the year 2001 (Strauss 2009). Specific and nonspecific symptoms of apple proliferation diseased plants are early reddening of leaves, a reduced root system, smaller leaves, enlarged stipules and through proliferation of axillary buds caused formation of witches' brooms as the most noticeable symptom (Bovey 1961; Seemüller et al. 2011). A considerable yield reduction of marketable fruits is either brought about by both weight and size reductions as well as a quality loss, namely the poor taste of apple fruits harvested from infested trees (Bovey 1961; Seemüller et al. 2011). Thereby, the infection of apple trees occurs in a persistent manner. Even though wide parts of the phloem are degenerated in winter, the phytoplasma was detected throughout the whole year, at least in the roots of infected apple trees (Schaper and Seemüller 1982). In spring, a recolonization of the stem with the phytoplasma was reported (Pedrazzoli et al. 2008; Schaper and Seemüller 1984).

There are a number of natural and artificial ways in which the transmission of ' $\mathrm{Ca}$. P. mali' takes place (Seemüller et al. 2011; Weintraub and Beanland 2006): the phytoplasma is either transferred by grafting of infected plant parts to healthy plantlets (Schaper and Seemüller 1982), or through the connection of sieve element tissue between infected and non-infected plants, for example through the formation of root bridges (Ciccotti et al. 2008) or by the parasitic dodder plant Cuscuta subinclusa (Carraro et al. 1988). Primarily, however, phytoplasmas are transmitted in a persistent-propagative way during phloem-feeding activities of sap-sucking insect vectors (Hogenhout et al. 2008; Lee et al. 2000; Weintraub and Beanland 2006).

Acquisition of ' $\mathrm{Ca}$. P. mali' from infected and transmission to healthy apple trees was proven for the summer apple psyllid Cacopsylla picta (Foerster, 1848), formerly known as Cacopsylla costalis (Flor, 1861) (Frisinghelli et al. 2000; Jarausch et al. 2010; Jarausch et al. 2011; Mayer et al. 2008a, b; Pedrazzoli et al. 2007). So far, C. picta is the only known vector of ' $\mathrm{Ca}$. P. mali' in Germany (Jarausch et al. 2003; Mayer et al. 2009). In southwest Germany and eastern France, a natural infection rate with the phytoplasma of approximately $10 \%$ was reported (Jarausch et al. 2011). The summer apple psyllid $C$. picta completes one generation, annually (Jarausch et al. 2019). During its lifetime, C. picta performs two host switches namely from apple, where nymphal stages develop and the adults of the new generation (named emigrants) hatch, which migrate to conifers, where they spend the rest of summer, autumn and winter. Because of the latter, conifers are termed as overwintering hosts (Mayer et al. 2011). The second host switch occurs during the following spring, when the overwintered adults (now named remigrants) remigrate into the apple orchards to their reproduction host plant apple, following the terminology of Mayer and Gross (2007) and Mayer et al. (2009), for mating and reproduction. In southwest Germany remigrants were caught mainly between March and April and emigrants mainly from May to June. The assumption of a polycyclic vector model by Jarausch et al. (2011) is supported by studies demonstrating both remigrants' and emigrants' ability to transmit ' $\mathrm{Ca}$. P. mali' (Carraro et al. 2008; Jarausch et al. 2004, 2011, 2013; Mattedi et al. 2008; Oppedisano et al. 2020) during phloem feeding.

The phloem of angiosperms is considered to be responsible mainly for long distance translocation of photoassimilates and other solutes through sieve elements (van Bel 2003). Substances such as carbohydrates, amino acids and minerals are regularly transported by the phloem (Gallinger and Gross 2020; Hijaz and Killiny 2014; Kollar and Seemüller 1990; van Bel 2003), but also defense and alarm signals (van Bel 2003; Will et al. 2013). Furthermore, even plant pathogens such as phytoplasmas are distributed by the phloem within the entire plant (Schaper and Seemüller 1982, 1984). Translocation of phloem sap thereby follows a pressure-flow and occurs from sites with higher towards sites of lower turgor pressure, thus from source to sink (Minchin and Lacointe 2005; van Bel 2003). Plants' photoassimilates producing organs such as mature leaves, act as sources, whereas assimilate consuming or storing organs, such as developing leaves and roots, act as sinks (Minchin and Lacointe 2005; Turgeon 1989).

Phytoplasma infection, however, may alter the phloem composition in infected plants as previous studies have shown (Gai et al. 2014; Giorno et al. 2013; Lepka 1999; Maust et al. 2003). Moreover, behavior and fitness of vector and non-vector species was strongly influenced in correlation with differences in host plant phloem composition and particularly with regard to infected vs. non-infected plants (Gallinger and Gross 2020; Mayer et al. 2011; Pradit et al. 2019). Some phloem-feeders, like the Asian citrus psyllid (Diaphorina citri), oviposit and develop exclusively on young shoots (Grafton-Cardwell et al. 2013). Setamou et al. (2016) found that the preference of $D$. citri for flush shoots was correlated with the abundance of essential amino acids and the $\mathrm{C}: \mathrm{N}$ ratio of phloem exudates. Cysteine, methionine and taurine were only detectable in phloem exudates from preferred young flush shoots. Consistently, Steinbauer (2013) revealed that higher concentrations of methionine, valine and threonine in apical buds of Eucalyptus globulus were associated with higher abundances of the blue gum psyllid Ctenarytaina eucalypti. Furthermore, a weak positive correlation between the fecundity of Ctenarytaina bipartita and the concentration of cysteine was found by 
Steinbauer et al. (2016), indicating that the nutritional quality is an important factor influencing the behavior and fitness of psyllids.

Therefore, we assessed the impact of ' $\mathrm{Ca}$. P. mali' infection on the phloem composition of apple plants and investigated possible effects on the host acceptance behavior of the vector insect $C$. picta. Host plant acceptance, per definition, occurs when sustained feeding or oviposition takes place (Schoonhoven et al. 2005). Hence, considering the additional trophic level of the pathogen seemed inevitable as the relation between a phloem-feeding vector and its host plant might be impacted by a phloem-borne pathogen sharing the same medium.

Firstly, the interaction of the phloem-dwelling bacterium ' $C a$. P. mali' with its host plant was evaluated. Therefore, we analyzed sugar, sugar alcohol and organic acid composition of phloem centrifugates of non-infected and infected apple trees. Secondly, we investigated the host acceptance behavior of the vector $C$. picta in binary-choice oviposition bioassay on apple plants infected and non-infected with ' $\mathrm{Ca}$. P. mali'. Physiological changes of the shared host plant were discussed in context to vector's oviposition choice. Finally, the importance of this multitrophic interaction of the vectorphytoplasma-plant-system was considered with regard to the epidemiology of ' $\mathrm{Ca}$. P. mali' and to pest control approaches of the vector $C$. picta.

\section{Material and methods}

\section{Insect collection and rearing}

In March and April 2019, C. picta remigrants were collected from an extensively managed apple orchard in Dossenheim, Germany, by beating tray method (Müther and Vogt 2003). Species identification was carried out using the key of Ossiannilsson (1992). Rearing took place on healthy potted $M$. domestica cv. Golden Delicious plants in $47.5 \times 47.5 \times 93 \mathrm{~cm}$ BugDorm rearing cages (NHBS, Devon, UK) located in a climatic chamber with $20^{\circ} \mathrm{C}$ day and $15^{\circ} \mathrm{C}$ night temperatures under long-day conditions (L16:D8) and $55 \%$ relative humidity.

\section{Plants}

Experiments were conducted with potted $M$. domestica cv. Golden Delicious plants grafted on M. domestica rootstocks (cv. M9) grown at Julius Kühn-Institut (JKI), Institute for Plant Protection in Fruit Crops and Viticulture (Dossenheim, Germany, 2012). Trees were either non-infected (- 'Ca. P. mali') or graft inoculated (+ 'Ca. P. mali') with the virulent apple proliferation phytoplasma strain $3 / 6$ (Seemüller et al. 2010, 2013). During the vegetative period, plants were kept in 7-1 pots in an insect-proof screenhouse (April-October) and watered daily. In spring 2018 and 2019 all plants were treated with acaricides Hexythiazox (Ordoval@, BASF, Ludwigshafen am Rhein, Germany) and Fenpyroximate (Kiron®, Cheminova Deutschland $\mathrm{GmbH}$ \& Co. KG, Stade, Germany). Pruning was done in June 2018 (after shoot harvest for phloem sap collection) and in February 2019. All flower buds were manually removed in April 2018 and 2019. Alternating treatments with myclobutanil (SysthaneTM20 EW, Corteva Agriscience, Munich, Germany), trifloxystrobin (Flint $®$, Bayer CropScience Deutschland $\mathrm{GmbH}$, Langenfeld, Germany) and triadimenol (Bayfidan ${ }^{\circledR}$, Cheminova Deutschland $\mathrm{GmbH} \& \mathrm{Co}$. KG, Stade, Germany) once a week were used to prevent mildew outbreak. Each year in October plant roots were treated with pirimicarb (Pirimor ${ }^{\circledR}$, Syngenta, Swiss) and a non-ionic additive (Break-thru ${ }^{\circledR}, \mathrm{AlzChem}$ Group $\mathrm{AG}$, Trostberg, Germany) against woolly apple aphids. In May 2018, a NPK-fertilizer (Triabon®, Compo Expert, Münster, Germany) was applied.

\section{Verification of phytoplasma infection in plants}

\section{DNA extraction}

Respective infection status of the plants was verified by DNA extraction, polymerase chain reaction (PCR) and gel electrophoresis. The DNA extraction method of plant material was adjusted according to Doyle and Doyle (1990). The leaf midrib was extracted by a scalpel. Between 50 and $300 \mathrm{mg}$ leaf midrib material was transferred into extraction bags (BIOREBA AG, Reinach, Switzerland) and ground in $2.5-3 \mathrm{ml}$ extraction buffer $(2.5 \%(\mathrm{w} / \mathrm{v})$ cetyltrimethylammonium bromide (CTAB) (Carl Roth $\mathrm{GmbH}+\mathrm{Co} . \mathrm{KG}$, Karlsruhe, Germany), $1.4 \mathrm{M} \mathrm{NaCl}$ (BerndKraft, Duisburg, Germany), $20 \mathrm{mM}$ ethylenediaminetetraacetic acid (EDTA) (Carl Roth GmbH + Co. KG, Karlsruhe, Germany), $100 \mathrm{mM}$ Tris(hydroxymethyl)aminomethane hydrochloride (Tris-HCl) pH 8.0 (Carl Roth $\mathrm{GmbH}+\mathrm{Co}$. KG), 1\% (w/v) polyvinylpyrrolidone 40 (PVP) (Sigma-Aldrich/ Merck, Darmstadt, Germany)) and 0.2\% (v/v) 2-mercaptoethanol (Carl Roth $\mathrm{GmbH}+\mathrm{Co}$. KG) using a homogenizer (BIOREBA AG). One milliliter of the homogenate was transferred into a microcentrifuge tube and incubated for $30 \mathrm{~min}$ at $60{ }^{\circ} \mathrm{C}$, before the $1: 1$ amount $(1 \mathrm{ml})$ of chloroform (Sigma-Aldrich) was added. The reaction tube was briefly vortexed and subsequently shaken for $10 \mathrm{~min}$ (stage 5, Universal Shaker SM 1, Edmund Bühler GmbH, Bodelshausen, Germany) at room temperature. After centrifugation at $13,000 \mathrm{rpm}$ for $6 \mathrm{~min}$ at room temperature (Centrifuge 5430 R, Eppendorf, Hamburg, Germany), the aqueous phase was transferred into a new reaction tube containing $750 \mu \mathrm{l}$ isopropanol (Sigma-Aldrich). The tube was inverted 
and kept at $-20{ }^{\circ} \mathrm{C}$ overnight, to allow the precipitation of nucleic acids. Precipitate was recovered by centrifugation at $13,000 \mathrm{rpm}$ for $10 \mathrm{~min}$ at room temperature. The supernatant then was discarded and the nucleic acid pellet was washed twice with $70 \%$ ethanol and centrifuged at 13,000 rpm for $10 \mathrm{~min}$ at room temperature. Subsequently, the pellet was air dried and resuspended in $25 \mu \mathrm{l}$ Tris-EDTA $\mathrm{pH}$ 9. Leaves of phytoplasma infected or healthy tobacco plants (Nicotiana tabacum L.) were used as positive or negative control, respectively.

\section{PCR}

For amplification of phytoplasma DNA fragments the primer pair fO1/rO1, derived from ' $\mathrm{Ca}$. P. mali' 16S rRNA gene (Lorenz et al. 1995), was used. One microliter of the DNA extract was added to $8.95 \mu$ HPLC water (VWR International $\mathrm{GmbH}$ ), $1.25 \mu \mathrm{l} 10 \times$ reaction buffer A (Nippon Genetics Europe GmbH, Düren, Germany), $0.25 \mu \mathrm{dNTPs}$ (10 mM each, Steinbrenner Laborsysteme GmbH, Wiesenbach, Germany), $0.5 \mu \mathrm{l}$ of each primer (10 $\mu \mathrm{M}$, Eurofins Genomics Germany GmbH, Ebersberg, Germany) and $0.05 \mu \mathrm{l}(1 \mathrm{U})$ of Taq DNA Polymerase FastGene (Nippon Genetics Europe $\mathrm{GmbH}$ ). Amplification parameters in the Thermo Cycler Gene Touch (Hangzhou Bioer Technology Co. Ltd., Hangzhou, China) were $2 \mathrm{~min}$ at $95^{\circ} \mathrm{C}$ followed by 35 cycles at $95^{\circ} \mathrm{C}$ for $20 \mathrm{~s}, 55^{\circ} \mathrm{C}$ for $20^{\circ} \mathrm{s}, 72^{\circ} \mathrm{C}$ for $45 \mathrm{~s}$ and finally $72{ }^{\circ} \mathrm{C}$ for $5 \mathrm{~min}$. The PCR amplification products were analyzed by $1 \%$ agarose gel electrophoresis (10 g agarose (Carl Roth $\mathrm{GmbH}+\mathrm{Co}$. KG) in $1000 \mathrm{ml} 100 \times \mathrm{TAE}$ buffer (484 g TRIS (Carl Roth GmbH + Co. KG), 114,2 ml acetic acid (Sigma-Aldrich), $200 \mathrm{ml}$ EDTA pH 8)), stained with ethidium bromide $(15 \mu \mathrm{l} / \mathrm{L})$. To the PCR amplification product $2 \mu \mathrm{l} 6 \times$ DNA Loading Dye (Fermentas/Fisher Scientific $\mathrm{GmbH}$, Schwerte, Germany) was added. The gel electrophoresis was performed at $90 \mathrm{~V}, 400 \mathrm{~mA}$ for 20 min using power supply BIO RAD Power Pac 300 (Bio-Rad Laboratories GmbH Deutschland, Feldkirchen, Germany). The ' $\mathrm{Ca}$. P. mali' DNA specific band was expected at 1048 bp compared to the corresponding band of $1 \mathrm{~kb}$ PLUS DNA Ladder (Fermentas/Fisher Scientific GmbH, Schwerte, Germany).

\section{Phloem sap collection}

Phloem sap collection was carried out according to Hijaz and Killiny (2014) using the centrifugation technique. In June 2018, 4-8 fresh green apple shoots (ca. $15 \mathrm{~cm} /$ plant) from non-infected and infected plants were cut and leaves were removed. Using a clean razorblade, the bark was detached and sliced into 1-2 cm pieces. The bottom tip of a small $0.5 \mathrm{ml}$ reaction tube (Sarstedt, Nürnbrecht, Germany) was removed using a sharp scalpel. Filled with the previously prepared bark pieces, the smaller reaction tube was placed inside an intact $1.5 \mathrm{ml}$ SafeSeal reaction tube (Sarstedt, Nürnbrecht, Germany Germany). The phloem sap was collected in the $1.5 \mathrm{ml}$ reaction tube after centrifugation with $13,000 \mathrm{rpm}$ at $4{ }^{\circ} \mathrm{C}$ for $10 \mathrm{~min}$ (Biofuge fresco, Heraeus, Osterode, Germany). The samples collected were stored at $-80^{\circ} \mathrm{C}$ until analysis.

\section{Sugar content}

The refractive index was assessed to determine the relative density $\left[{ }^{\circ}\right.$ Brix] representing the total soluble sugar content of the phloem sap. Approximately $1 \mu \mathrm{l}$ per defrosted phloem centrifugate (- 'Ca. P. mali' $N=16,+{ }^{~ ' C a}$. P. mali' $N=17$ ) was applied to a handheld refractometer (type 45-81; Bellingham + Stanley Ltd., Tunbridge Wells, UK) at room temperature. The refractometer was standardized for sucrose.

\section{Derivatization}

The phloem sap samples were derivatized with trimethylsilyl (TMS) to focus the GC-MS analysis on sugars and organic acids according to Gallinger and Gross (2020). Ribitol (Sigma-Aldrich Chemie GmbH, Munich, Germany) was used as internal standard. To $60 \mu$ internal standard ( $1.5 \mathrm{mmol}$ ribitol in ultrapure water) $5 \mu \mathrm{l}$ of defrosted phloem sap was added and dried under nitrogen stream (Reacti-Vap, Thermo Fisher Scientific Inc., Waltham, MA, United States). To each dried sample, $70 \mu$ methoxyamine hydrochloride solution (MOX) in pyridine (2\%) was added and incubated for $90 \mathrm{~min}$ at $37^{\circ} \mathrm{C}$. During incubation stirring adjustment was set to 6 (Reacti-Therm, Thermo Fisher Scientific Inc., Waltham, MA, United States). Finally, addition of $100 \mu \mathrm{l}$ $N$-methyl- $N$-(trimethylsilyl) trifluoroacetamide (MSTFA) started the silylation process for $60 \mathrm{~min}$ at $37{ }^{\circ} \mathrm{C}$ and stirring stage 6 (Reacti-Therm, Thermo Fisher Scientific Inc.). The supernatant was then transferred into a fresh GC-MS vial with glass insert ( - ' $C a$. P. mali' $N=13,+$ ' $C a$. P. mali' $N=14$ ). Reference standards and respective suppliers were used according to Gallinger and Gross (2020).

\section{Gas chromatography coupled with mass spectrometry (GC-MS)}

Derivatized samples were analyzed according to Gallinger and Gross (2020) by gas chromatography coupled with mass spectrometry (GC-MS) using a PerkinElmer Clarus R 680 GC system coupled to a Perkin Elmer quadrupole inert mass selective detector. For GC separation a nonpolar Elite-5MS (Crossbond 5\% diphenyl-95\% dimethyl polysiloxane, PerkinElmer $)$ capillary column $(30 \mathrm{~m} \times 0.25 \mathrm{~mm}$ id $\times 0.25 \mu \mathrm{m}$ film thickness) was used, with helium (Helium 6.0, Air Liquide, 
Germany) as carrier gas. Carrier gas flow rate was about $5 \mathrm{ml} / \mathrm{min}$ and column head pressure set to $130 \mathrm{kPa}$.

Injection of $1.5 \mu \mathrm{TMS}$-derivatized sample was performed with a split flow of $5 \mathrm{ml} / \mathrm{min}$ at $140{ }^{\circ} \mathrm{C}$. The injector temperature was then increased to $250{ }^{\circ} \mathrm{C}$ at a rate of $50 \mathrm{~K} / \mathrm{min}$. Carrier gas flow rate was about $5 \mathrm{ml} / \mathrm{min}$ and split flow rate was $5 \mathrm{ml} / \mathrm{min}$, too. The $\mathrm{GC}$ oven temperature program was as follows: initial temperature of $80^{\circ} \mathrm{C}$ was held for $3 \mathrm{~min}$, then increased to $320^{\circ} \mathrm{C}$ at a rate of $5 \mathrm{~K} / \mathrm{min}$ and held for $4 \mathrm{~min}$. Detection started after a solvent delay of 6 min. During all analyses, transfer line and ion source were set to $250{ }^{\circ} \mathrm{C}$ and $180^{\circ} \mathrm{C}$, respectively. The quadrupole mass detector was operated in electron-impact (EI) mode at $70 \mathrm{eV}$. All data were obtained by collecting the full-scan mass spectra within the range of $35-550 \mathrm{~m} / \mathrm{z}$. Blank samples, reference standards and mixtures of alkanes $(\mathrm{C} 10-\mathrm{C} 40)$ were additionally analyzed with the same settings.

\section{Analysis with AMDIS}

Evaluation of GC-MS chromatograms from phloem sap samples was carried out using "Automated Mass Spectral Deconvolution and Identification System" (AMDIS, Version 2.73, National Institute of Standards and Technology NIST, Boulder, CO, United States). Identification of detected compounds was conducted by comparing ion fragmentation patterns and retention indices to those of standard compounds (Gross et al. 2019a). Unidentified compounds were marked as "unknown". In AMDIS, the peak area of each compound was integrated after deconvolution to allow quantification. As identification requirements a minimum match factor of $\geq 80 \%$ and a relative retention index deviation of $\leq 5 \%$ from reference value were set as limits. Settings for deconvolution were as follows: component width of 32 ; adjacent peak subtraction, one; resolution, medium; sensitivity, medium; shape requirements, medium. For compounds with more than one derivate per substance, only the highest peak was taken into account (Villas-Bôas et al. 2011). Only compounds with a signal-to-noise ratio $\geq 50$ were included into further analysis. Proportions of derivates detected were normalized to the internal standard ribitol.

\section{Binary-choice oviposition bioassay}

For conducting binary-choice oviposition bioassay, two leaves, each from non-infected and from infected apple plants (BBCH scale for pome fruit 69: end of flowering; Meier et al. 1994) were offered simultaneously. Therefore, one leaf of each tree was inserted from opposite sides into a gauze tube $(20 \times 30 \mathrm{~cm})$. After an acclimatization period of at least 6 days under rearing conditions, one female C. picta remigrant was placed in the middle of each bag and left to oviposit for 4 days (96 h). Afterwards, the leaves were removed and stored at $-20{ }^{\circ} \mathrm{C}$ until assessment with a binocular stereomicroscope (Stemi 508, Carl Zeiss AG, Oberkochen, Germany). Location and number of eggs were noted. The experiment was replicated with $22 C$. picta females under rearing conditions.

\section{Statistics}

All statistical analyses were run in R (Version 1.2.5033, (RStudio Team 2019)). If not otherwise stated, all figures were generated using the "ggplot2" package (Wickham et al. 2019).

\section{Sugar content}

To compare the refractive index $\left[{ }^{\circ} \mathrm{Brix}\right]$ representing the amount of total soluble sugar content, a linear regression model (LM) was fitted (Crawley 2012). Assessment of compliance with model assumptions was done visually (Zuur et al. 2009) and the best model identified by Akaike information criterions (AIC). Comparison between effects due to infection status of the host plant was calculated with estimated marginal means and 95\% confidence intervals with the function emmeans from "emmeans" package (Lenth et al. 2019). Significance levels were set to $p<0.05$.

\section{Phloem composition}

With the normalized amount of phloem sap compounds a Bray-Curtis dissimilarity matrix was calculated to test for discrimination between phloem composition of ' $\mathrm{Ca}$. P. mali' infected and non-infected plants by permutational analysis of variance (PERMANOVA) with adonis2 from the "vegan" package (Oksanen et al. 2019). Additionally, it was tested for multivariate homogeneity of group dispersion or permutational dispersion (PERMDISP) with betadispr (Vegan package). Both procedures were calculated with $N=10,000$ permutations. For the scaling of TMS derivates a Wisconsin double standardization was applied. Non-metric multidimensional scaling (NMDS) plots were used to visualize Bray-Curtis dissimilarities. For 3-dimensional presentation the ordiplot $3 d$ function from the "vegan $3 \mathrm{~d}$ " package (Oksanen et al. 2018) was used. To compare the total amount of sugars, sugar alcohols, organic and amino acids as well as sucrose, sorbitol and malic acid levels in phloem samples of non-infected and ' $\mathrm{Ca}$. P. mali' infected plants, linear models (LMs) were fitted as described above. The model regarding the total amount of sugars, sugar alcohols, organic and amino acids was simplified by testing for non-significant interactions and effects according to F-Test and removal of non-significant terms $(p>0.05)$ using the dropl function. Multiple pairwise comparison between effects due to compound class and infection status of the host plant was 
calculated with estimated marginal means and 95\% confidence intervals with the function emmeans from "emmeans" package (Lenth et al. 2019) and $p$ values adjustment by the method of Tukey. For model specifications Online Resource 1.

\section{Binary-choice oviposition bioassay}

Differences in number of eggs laid on non-infected or infected leaves were evaluated by fitting a generalized linear model with the logarithmized total number of eggs per insect as offset. Due to overdispersion, a negative binomial model with the function glm.nb from "MASS" package (Ripley et al. 2019) was used. Model selection was done by Akaike information criterions (AIC). Differences in oviposition choice depending on infection status of the host plant were calculated using estimated marginal means and 95\% confidence intervals with the function emmeans from "emmeans" package (Lenth et al. 2019). Significance levels were set to $p<0.05$.

\section{Results}

\section{Phloem sap}

\section{Sugar content}

The plants infection status had a significant influence on Brix value of phloem sap samples (LM, $F=12.73, d f=1,31$, $p=0.001$ ) with increased values in ' $C a$. P. mali' infected plants compared to non-infected apple plants (Fig. 1).

\section{Phloem composition}

After GC-MS analysis and AMDIS evaluation, eight sugar and sugar alcohols, five amino acids and six other organic acids (and six unidentified substances) were found for TMS derivates (Online Resource 1). The two-dimensional visualization in NMDS plots showed high stress values for TMS derivates $\left(\mathrm{TMS}_{2 \mathrm{D}}\right.$ : stress $\left.=0.169\right)$, enabling the presentation in a 3D format $\left(\mathrm{TMS}_{3 \mathrm{D}}\right.$ : stress $\left.=0.101\right)$ (Fig. 2). Permutational dispersion was homogeneous between groups for TMS-derivatized phloem sap samples (PERMDISP, $F=0.3906, d f=1$, $p=0.521)$. The infection status had a significant effect on the discrimination between phloem sap samples after TMS derivatization (PERMANOVA, $F=11.713, d f=1,26, p<0.001$ ). Among the 18 substances responsible for the group separation between phloem samples (Table 1, for unidentified compounds s. Online Resource 2), sorbitol, sucrose and quinic acid were the compounds with the greatest quantities (sorbitol $>$ quinic acid $>$ sucrose). In general, more sugar and sugar alcohols were present in phloem samples from non-infected

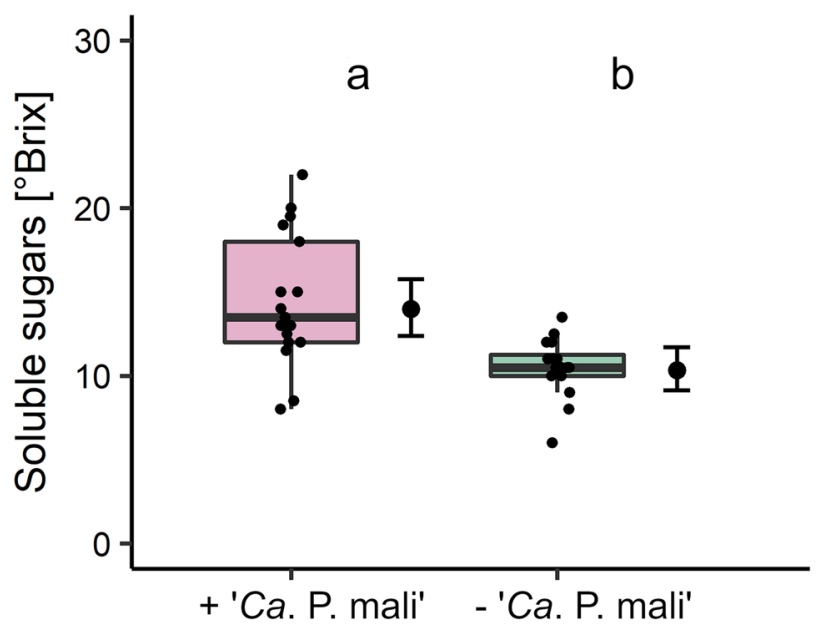

Fig. 1 Mean amount of total soluble sugar content $\left[{ }^{\circ} \mathrm{Brix}\right]$ in phloem centrifugates of phytoplasma infected (+ ' $\mathrm{Ca}$. P. mali', $N=17)$ and non-infected ( - 'Ca . P. mali', $N=16$ ) apple trees. Boxes correspond to the 25th and 75th percentiles, medians are shown as lines, and whiskers extend to 1.5 times of the interquartile ranges. Dots represent raw values. Corresponding means and confidence intervals predicted from linear model are shown to the right of each box

plants than organic acids, and within those, the amino acids occurred in lowest quantities (Fig. 3). In samples from ' $\mathrm{Ca}$. P. mali' infected plants, the relative amount of all sugar and sugar alcohols was significantly increased, whereas amino acid and other organic acid content was similar to non-infected plants (LM, $F=743, d f=5,75, p<0.0001$ ) (Fig. 3). Phloem sap of infected apple trees contained significantly higher amounts of sorbitol (LM, $F=13.18, d f=1,25, p=0.0013$; Fig. 4 a) and sucrose (LM, $F=7.022, d f=1,25, P=0.014$; Fig. $4 b$ ). Even though the relative amount of total organic acid content did not differ between samples, the malic acid concentration was significantly increased in ' $\mathrm{Ca}$. P. mali' infected plants (LM, $F=10.43, d f=1,25, p=0.0034$ ) (Fig. 4c).

\section{Binary-choice oviposition bioassay}

In oviposition binary-choice bioassays, $C$. picta females laid at least 2 and up to 100 eggs during the experiment runtime of $96 \mathrm{~h}$. During the experiment, remigrant females laid significantly more eggs on leaves of non-infected apple trees $(63.0 \pm 10.4 \%)$ than on ' $\mathrm{Ca}$. P. mali' infected trees $(36.2 \pm 6.2 \%)\left(\mathrm{GLM}, X^{2}=5.37, d f=1,43, p=0.021\right)$ (Fig. 5).

\section{Discussion}

Corresponding to our results, earlier studies described sucrose and sorbitol to be the most abundant sugar and sugar alcohol within the plant family Rosaceae. These metabolites 


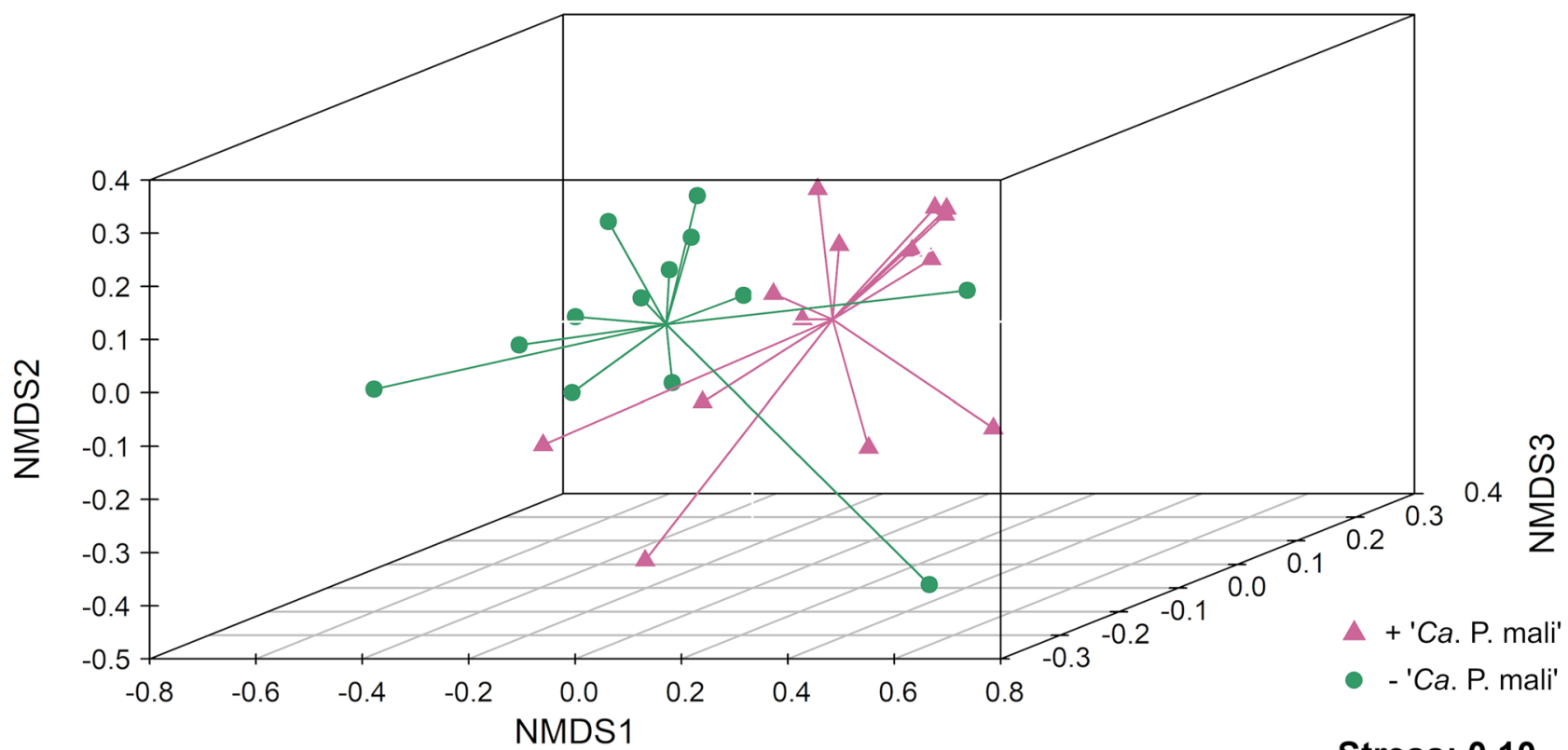

Stress: 0.10

Fig. 2 Visualization of Bray-Curtis dissimilarities with non-metric multidimensional scaling (NMDS) plots of composition of phloem centrifugates of phytoplasma infected ( + ' $C a$. P. mali', $N=14$, red tri-

have been detected in apple sieve tube content (Kollar and Seemüller 1990), pear phloem exudate (Le Goff et al. 2019), and Prunus sp. phloem centrifugates (Gallinger and Gross 2018, 2020). In general, the photosynthesis products sucrose and sorbitol are known to be among the predominant sugars involved in phloem transport (Bieleski 1969; Loescher 1987; Reidel et al. 2009; Rosa et al. 2009; van Bel 2003). Additionally, the findings of malic and citric acid as predominant organic acids (Kollar and Seemüller 1990) were in accordance with the high concentrations we found in our samples. However, we found quinic acid to be the organic acid with the highest abundance in apple phloem. Although Kollar and Seemüller (1990) could not detect cysteine and arginine, they found 18 other amino acids, whereas we only detected asparagine, aspartic acid, alanine, serine and threonine. Most probably, the different findings were caused by distinct methods used to obtain sap samples, analysis methods and respective detection limits. The GC-MS analysis of TMS derivates used in our study reached their limits particularly for the detection of amino acids, which would be of notably lower concentration in comparison to sugars (Le Goff et al. 2019). Kollar and Seemüller (1990) concluded from their results of exudates obtained by incision method solely of apple proliferation diseased plants that sieve tube content would not be significantly altered by phytoplasma infection. As a result of our study, however, we found evidence that phloem composition differed significantly between ' $\mathrm{Ca}$. P. mali' infected and non-infected apple plants with increased angles) and non-infected (- ' $\mathrm{Ca}$. P. mali', $N=13$, green circles) apple trees after silylation

soluble sugar content ( ${ }^{\circ}$ Brix), increased sugar and sugar alcohol concentrations, such as sorbitol and sucrose in ' $C a$. P. mali' infected plants. These results are in accordance to findings from Lepka (1999) working on tobacco (Nicotiana tabacum) and periwinkle plants (Catharanthus roseus) infected with ' $C a$. P. mali'. The results of their study on the content of source (mature leaves) and sink organs (roots and young leaves) suggested that carbohydrate translocation was severely affected by ' $C a$. P. mali' infection. The transport of photoassimilates from mature leaves to roots and young leaves seemed obstructed. Similar effects of inhibited sugar transport during the progression of lethal yellowing (LY) disease were described for phytoplasma-infected coconut trees (Cocos nucifera) (Maust et al. 2003). Additionally, a study on yellow dwarf-diseased mulberry plants (Morus multicaulis) showed that phytoplasma infection induced accumulation of soluble carbohydrates such as sucrose in mulberry leaves, but also phloem sap extracts (Gai et al. 2014). It is assumed that the transportation of sucrose from source organs into the phloem is conducted by sucrose symporters against a concentration gradient (Bush 1992). Even though an accumulation of sucrose was observed in source organs of infected mulberry plants, the relocation of carbohydrates into the phloem, however, seemed not inhibited as the relative gene expression of the key protein, the sucrose symporter, was increased in infected plants (Gai et al. 2014). These results could explain the presence of sucrose not only in source organs but also in the phloem, although 
Table 1 Mean relative amounts $( \pm \mathrm{SD})$ of phloem metabolites detected via GC-MS analysis after derivatization

\begin{tabular}{|c|c|c|c|c|c|c|c|}
\hline Class & Compound & Retention index & Infection status & Mean & \pm & SD & PERMANOVA \\
\hline \multirow[t]{16}{*}{ Sugars and sugar alcohols } & \multirow[t]{2}{*}{ Sorbitol } & \multirow[t]{2}{*}{1933} & $+^{\prime} C a$. P. mali' & 27.773 & \pm & 8.038 & \multirow[t]{2}{*}{$* * *$} \\
\hline & & & - 'Ca. P. mali' & 16.759 & \pm & 4.448 & \\
\hline & \multirow[t]{2}{*}{ Sucrose } & \multirow[t]{2}{*}{2629} & + 'Ca. P. mali' & 4.246 & \pm & 2.82 & \multirow[t]{2}{*}{$* * *$} \\
\hline & & & - 'Ca. P. mali' & 1.537 & \pm & 0.639 & \\
\hline & \multirow[t]{2}{*}{ Glucose } & \multirow[t]{2}{*}{$1895 / 1912$} & $+^{\prime} C a$. P. mali' & 0.889 & \pm & 0.942 & \multirow[t]{4}{*}{$* * *$} \\
\hline & & & - 'Ca. P. mali' & 0.742 & \pm & 0.337 & \\
\hline & \multirow[t]{2}{*}{ Fructose } & \multirow[t]{2}{*}{$1869 / 1885$} & $+^{\prime} C a$. P. mali' & 0.749 & \pm & 0.269 & \\
\hline & & & - 'Ca. P. mali' & 0.423 & \pm & 0.133 & \\
\hline & \multirow[t]{2}{*}{ Galactose } & \multirow[t]{2}{*}{$1887 / 1908$} & +'Ca. P. mali' & 0.684 & \pm & 0.897 & \multirow[t]{10}{*}{$* * *$} \\
\hline & & & - 'Ca. P. mali' & 0.11 & \pm & 0.398 & \\
\hline & \multirow[t]{2}{*}{ Myo-inositol } & \multirow[t]{2}{*}{2086} & $+^{\prime} C a$. P. mali' & 0.058 & \pm & 0.02 & \\
\hline & & & - 'Ca. P. mali' & 0.065 & \pm & 0.018 & \\
\hline & \multirow[t]{2}{*}{ Mannitol } & \multirow[t]{2}{*}{1926} & $+{ }^{\prime C a}$. P. mali' & 0.036 & \pm & 0.015 & \\
\hline & & & - 'Ca. P. mali' & 0.021 & \pm & 0.009 & \\
\hline & \multirow[t]{2}{*}{ Maltose } & \multirow[t]{2}{*}{2728} & $+^{\prime} C a$. P. mali' & 0.006 & \pm & 0.013 & \\
\hline & & & - 'Ca. P. mali' & 0 & \pm & 0 & \\
\hline \multirow[t]{12}{*}{ Organic acids } & \multirow[t]{2}{*}{ Quinic acid } & \multirow[t]{2}{*}{1856} & $+^{\prime C}$. P. mali' & 6.67 & \pm & 0.812 & \\
\hline & & & - 'Ca. P. mali' & 5.268 & \pm & 2.052 & \\
\hline & \multirow[t]{2}{*}{ Malic acid } & \multirow[t]{2}{*}{1489} & $+^{\prime C}$ Ca. P. mali' & 0.523 & \pm & 0.199 & $* *$ \\
\hline & & & - 'Ca. P. mali' & 0.326 & \pm & 0.096 & \\
\hline & Citric acid & 1817 & $+^{\prime} C a$. P. mali' & 0.131 & \pm & 0.076 & $* * *$ \\
\hline & & & - 'Ca. P. mali' & 0.082 & \pm & 0.032 & \\
\hline & Shikimic acid & 1810 & $+{ }^{\prime C a}$. P. mali' & 0.006 & \pm & 0.005 & $* * *$ \\
\hline & & & - 'Ca. P. mali' & 0.003 & \pm & 0.005 & \\
\hline & Phosphoric acid & 1271 & +'Ca. P. mali' & 0.01 & \pm & 0.012 & $* * *$ \\
\hline & & & - 'Ca. P. mali' & 0.007 & \pm & 0.015 & \\
\hline & Succinic acid & 1317 & +'Ca. P. mali' & 0.001 & \pm & 0.003 & \\
\hline & & & - 'Ca. P. mali' & 0.001 & \pm & 0.003 & \\
\hline Amino acids & Aspartic acid & $1420 / 1519$ & +'Ca. P. mali' & 0.009 & \pm & 0.008 & $* * *$ \\
\hline & & & - 'Ca. P. mali' & 0.004 & \pm & 0.007 & \\
\hline & Alanine & 1107 & $+^{\prime C a}$. P. mali' & 0.003 & \pm & 0.005 & $* * *$ \\
\hline & & & - 'Ca. P. mali' & 0.001 & \pm & 0.002 & \\
\hline & Asparagine & 1667 & $+^{\prime} C a$. P. mali' & 0.001 & \pm & 0.003 & $* *$ \\
\hline & & & - 'Ca. P. mali' & 0.008 & \pm & 0.022 & \\
\hline & Serine & $1254 / 1359$ & +'Ca. P. mali' & 0.002 & \pm & 0.005 & $* *$ \\
\hline & & & - 'Ca. P. mali' & 0.001 & \pm & 0.003 & \\
\hline & Threonine & $1290 / 1383$ & $+^{\prime} C a$. P. mali' & 0.001 & \pm & 0.003 & $* *$ \\
\hline & & & - 'Ca. P. mali' & 0.002 & \pm & 0.004 & \\
\hline
\end{tabular}

Amounts of sugars and sugar alcohols, organic acids and amino acids after silylation of phloem centrifugates of phytoplasma infected (+ 'Ca. P. mali', $N=14)$ and non-infected ( - 'Ca. P. mali', $N=13$ ) apple trees are relative to internal standard ribitol. Asterisks display significant influences $* *: p<0.01,{ }^{* * *}: p<0.001$ ) of the compounds in permutational analysis of variance (PERMANOVA), allowing the discrimination of phloem of infected and non-infected apple trees

the transport to sink organs might be restrained in infected plants. In this context, blockage of sieve tubes for example by callose decomposition as plant defense mechanism or limited translocation via reduced available translocation area resulting from phloem degradation are discussed in other studies (Braun and Sinclair 1978; Lepka 1999; Marco et al. 2016; Musetti et al. 2010). An early study suggested, however, that proper phloem transport in plants is already affected prior to the manifestation of histopathological symptoms (Braun and Sinclair 1978). It was hypothesized that sugars, especially sucrose as dominant transport sugar, play a role in signaling and sensing processes within the plant providing feedback on sugar status (Rosa et al. 2009; van Bel 2003). Hence, soluble sugar concentrations might 


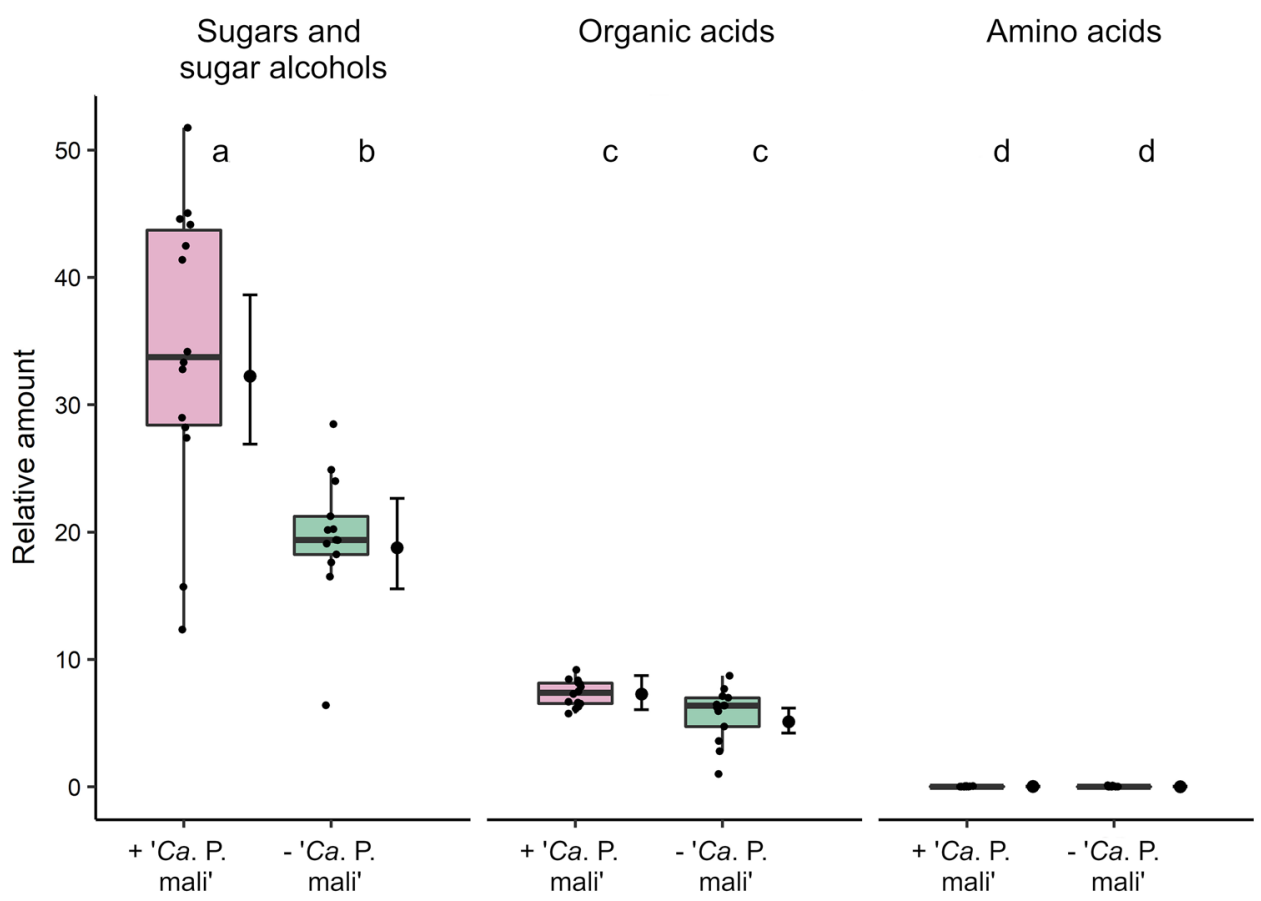

Fig. 3 Mean relative amount of total sugars and sugar alcohols, organic and amino acids from phloem centrifugates of phytoplasma infected (+' $\mathrm{Ca}$. P. mali', $N=14$ ) and non-infected (- 'Ca. P. mali', $N=13$ ) apple trees after silylation. Sugars and sugar alcohols (sorbitol, sucrose, glucose, fructose, galactose, myo-inositol, mannitol, maltose), organic acids exclusive of amino acids (quinic acid, malic acid, citric acid, shikimic acid, phosphoric acid, succinic acid) and amino acids (aspartic acid, alanine, asparagine, serine, threonine) after silylation have been quantified relative to internal standard ribitol. Boxes correspond to the 25th and 75th percentiles, medians are shown as lines, and whiskers extend to 1.5 times of the interquartile ranges. Dots represent raw values. Corresponding means and confidence intervals predicted from linear model are shown to the right of each box (a)

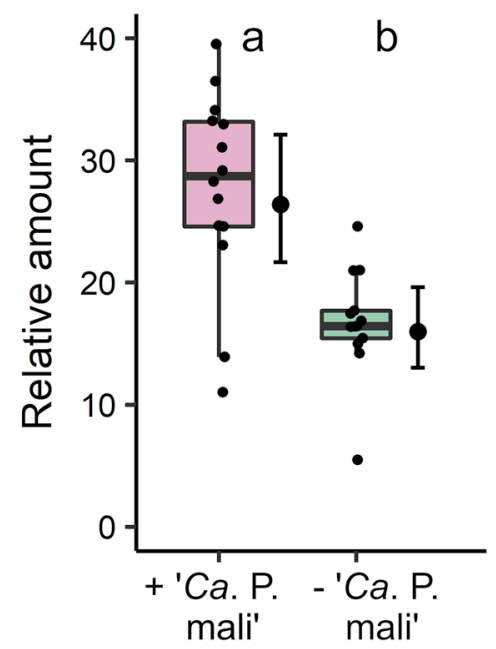

(b)

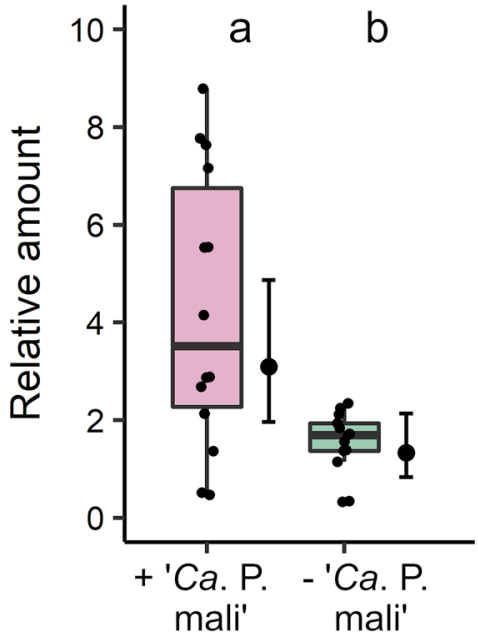

(c) Malic acid

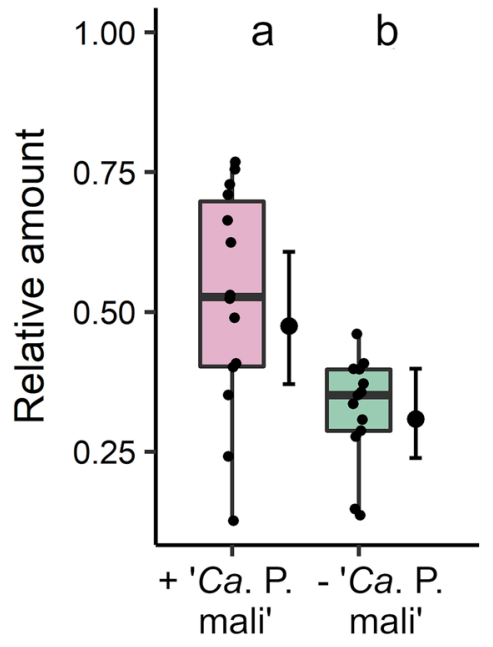

Fig. 4 Mean relative amount of sorbitol (a), sucrose (b) and malic acid (c) levels in phloem centrifugates of phytoplasma infected (+ 'Ca. P. mali', $N=14$ ) and non-infected (- 'Ca. P. mali', $N=13$ ) apple trees after silylation. All compounds have been quantified relative to internal standard ribitol. Boxes correspond to the 25 th and 75th percentiles, medians are shown as lines, and whiskers extend to 1.5 times of the interquartile ranges. Dots represent raw values. Corresponding means and confidence intervals predicted from linear model are shown to the right of each box 


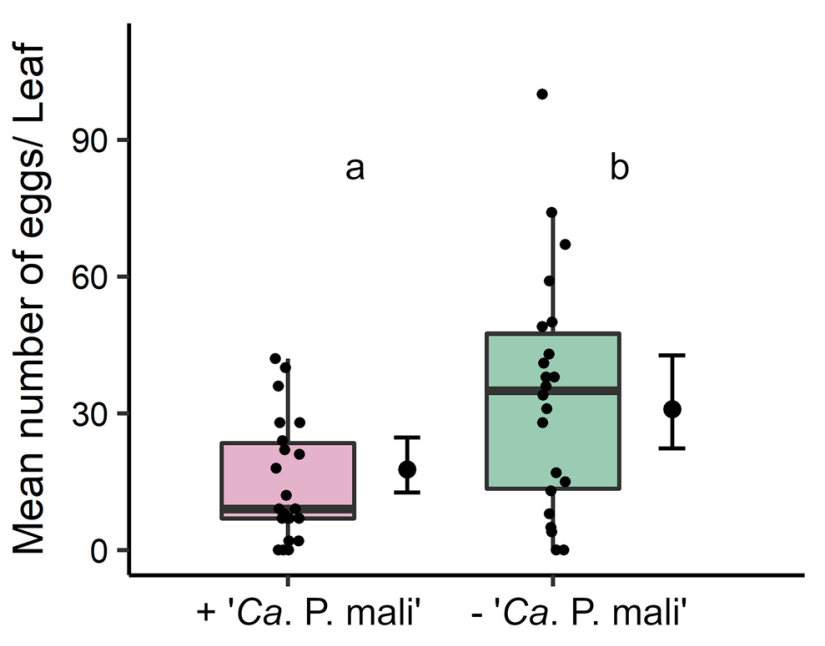

Fig. 5 Mean number of eggs per leaf on phytoplasma infected (+'Ca. P. mali') and non-infected ( $($ 'Ca. P. mali') apple trees $\left(N_{C . \text { picta }}=22\right)$. Boxes correspond to the 25 th and 75 th percentiles, medians are shown as lines, and whiskers extend to 1.5 times of the interquartile ranges. Dots represent raw values. Corresponding means and confidence intervals predicted from linear model are shown to the right of each box

be able to trigger alterations in gene expression and enzyme activities, consequently affecting metabolism and growth of source and sink tissues (Rosa et al. 2009).

So far, neither required substrate nor related metabolism mechanisms were unequivocally identified for ' $\mathrm{Ca}$. $\mathrm{P}$. mali' with its linear chromosome lacking genes encoding for major biosynthesis pathways including glycolysis (Kube et al. 2008, 2012; Siewert et al. 2014). However, results from genome characterization and transcriptome analysis of ' $\mathrm{Ca}$. P. mali' suggest a pathway from malate, the salt of malic acid, to acetate to gain energy in form of adenosine triphosphate (ATP) (Kube et al. 2008; Siewert et al. 2014). In our present study, we found significantly increased concentrations of malic acid in phloem sap samples of ' $\mathrm{Ca}$. P. mali' infected plants (Fig. 4c). Currently we cannot provide evidence on the cause of the observed increase in sugar, sugar alcohols and malic acid. They might be directly caused by the phytoplasma acting as an additional sink, attempting to manipulate its host to provide increased nutrient levels in the phloem, or might be the result of plant defense reactions against the pathogen. This uncertainty will remain until the establishment of a reproducible axenic cultivation system will allow experiments to gain insight into the nutritional requirements of ' $C a$. P. mali' (Kube et al. 2012).

Previously, Mayer et al. (2011) found that $C$. picta females laid increased numbers of eggs on non-infected leaves compared to numbers of eggs on ' $\mathrm{Ca}$. P. mali' infected apple leaves. However, for no-choice tests it cannot be completely excluded that the number of eggs laid by an insect might primarily be affected by the insect's individual oviposition motivation (Singer et al. 1992) and only secondarily by host plant attributes. Hence, we performed binary-choice bioassays to obtain reliable insights into $C$. pica's host preferences. Host plant preference is defined by the increased frequency of an insect's choice of a plant compared to the choice of an alternative (Schoonhoven et al. 2005), hence requires the option of choice. Our binary-choice bioassay showed that $C$. picta remigrants accepted infected and non-infected plants for oviposition, which was also shown in earlier no-choice experiments (Mayer et al. 2011). However, larger numbers of eggs were found on non-infected plants. This effect was also demonstrated in no-choice tests with the hawthorn psyllid $C$. melanoneura, a vector of ' $\mathrm{Ca}$. P. mali' in one specific geographical area (Tedeschi et al. 2002), which laid fewer eggs on ' $C a$. P. mali' infected apple shoots (Malagnini et al. 2010). The host recognition/ selection process in phloem-feeding insects is a complex series of steps on distinct spatial and temporal scales as was defined for aphids (Powell et al. 2006) and extended for other homopteran insects (Fereres and Moreno 2009). In general, physical and chemical stimuli affect host plant selection and acceptance (Cao et al. 2014; Dicke 2000; Fereres and Moreno 2009; Prokopy and Owens 1978; Sugio et al. 2011). Chemical stimuli, such as primary and secondary plant metabolites or phytohormones, were altered as result of the phytoplasma infection (Janik et al. 2017; Mayer et al. 2008a,b; Rid et al. 2016; Sugio et al. 2011; Zimmermann et al. 2015). Regarding these manifold morphological and physiological alterations reported after infection with ' $\mathrm{Ca}$. P. mali' in apple plants, it is not possible to link C. picta's oviposition preference on non-infected leaves to a single one of these effects. Thus, further oviposition choice experiments, e.g., with volatiles, leaf surface extracts or components from ' $C a$. P. mali' infected and non-infected plants are needed to better understand this behavior. However, for female insects choosing a plant suitable for oviposition, is to a lesser extent determining their own but rather the survival and fitness of their offspring, leading to continued existence of the whole population (Jaenike 1978). One key criterion for host plant suitability is the quality and quantity of nutrients available to the insects. As we were investigating phloem-feeding insects vectoring a phloem-dwelling pathogen, in the present study special regard was paid to phloem composition. The importance of phloem metabolites on fitness and development of psyllid offspring was recently demonstrated for the closely related psyllid Cacopsylla pruni by Gallinger and Gross $(2018,2020)$. Given the high amounts of sorbitol present in apple phloem, sorbitol might be of relevance for host plant recognition. For psyllid metabolism however, sorbitol might not be utilized in high amounts, as was shown for pear psyllid Cacopsylla pyri (Le Goff et al. 2019). In contrast, sucrose was metabolized to a greater extent than sorbitol by the pear psyllid (Le Goff et al. 2019). Moreover, 
feeding stimulation of sucrose for insects was demonstrated (Fontellas and Zucoloto 2003; Hewer et al. 2010; Mittler and Dadd 1963). Interestingly, the analyses of phloem sap samples in the present study showed not only that sugar and sugar alcohol levels increased in infected plants, but also that the amount of detected amino acids remained at the same level. Therefore, a shift in the amino acid:sugar ratio was evident, potentially rendering the host plant less suitable.

To satisfy their nutritional demands especially in regard to the amino acid content, phloem-feeding insects take up excessive amounts of sugar rich phloem sap and excrete the surplus sugars as honeydew (Ashford et al. 2000; Douglas 2006). Changes in phloem's amino acid:sugar ratio due to $C a$. P. mali infection, phloem feeding on infected plants would result in the uptake of reduced amino acid content and increased concentrations of sugars. Thus, changes in phloem composition may be responsible for increased mortality of C. picta nymphs and decreased body sizes of adults developed on ' $\mathrm{Ca}$. P. mali'-infected apple plants (Mayer et al. 2011). However, the availability of amino acids for psyllid nutrition cannot be exclusively determined by the amino acid abundance in the phloem. Endosymbiotic bacteria colonizing the phloem feeders gut synthesize (essential) amino acids from phloem compounds such as carbohydrates and provide the phloem-feeder with the surplus (Douglas 1998, 2006; Thao et al. 2000). Additionally, plant defense products are assumed to influence fitness and behavior of phloem-feeding insects, but the current state of knowledge is still insufficient (Ranger et al., 2006; Steinbauer et al. 2016). Furthermore, infection with apple proliferation phytoplasma results in seasonally varying phytohormone level changes such as effects on auxin (indole-3-acetic acid, IAA), abscisic acid (ABA), jasmonic acid (JA) and salicylic acid (SA) between infected and non-infected plants (Dermastia 2019; Janik et al. 2017; Musetti et al. 2013; Zimmermann et al. 2015). It is also known that alterations in phytohormone signaling processes subsequently impact the feeding and host selection behavior of herbivorous insects (Cao et al. 2014; Kallenbach et al. 2012; Sugio et al. 2011). It was shown that the phytoplasma effector SAP11 did not only induce phytohormonal changes in the common host plant, but also improved the performance of the vector insect Macrosteles quadrilineatus (Hemiptera: Cicadellidae) (Sugio et al. 2011). In fact, their study showed that this leafhopper vector laid more eggs on AY-WB-infected Arabidopsis thaliana.

At present, little is known about the nutritional demands of C. picta and potential regulatory mechanisms in host plant selection and feeding, demonstrating the need for further research. Our study provides the basis for feeding experiments with simplified artificial diets. Additionally, the analysis of honeydew excreted by the psyllids in relation to the composition of the offered medium could give valuable insight into the nutritional needs of $C$. picta. To prevent further distribution of apple proliferation disease we aim at controlling its vector $C$. picta. Plant-mediated stimuli might be identified based on our study findings. Hence, detected sugars and sugar alcohols or malic acid could be used as the starting point in the screening for potential attractive or deterrent compounds. Behavior modifying compounds could further be combined with the semiochemical $\beta$-caryophyllene, which is known to attract $C$. picta emigrants (Mayer et al. 2008a, b), for developing innovative approaches such as specific lures (Eben and Gross 2013; Gross et al. 2019b), or attract-and-kill strategies minimizing vector populations in the future (Gross 2013; Gross and Gündermann 2016).

Acknowledgements We thank Svenja Stein, Natalie Giesen and Thimo Braun (JKI, Dossenheim, Germany) for excellent assistance in the lab, Felix Hergenhahn (JKI, Dossenheim, Germany) for grafting and cultivation of the plants, and Dr. Doreen Gabriel (JKI, Braunschweig, Germany) for statistical advice regarding the binary-choice oviposition bioassay. We are grateful to Dr. Eva Gross (Schriesheim, Germany) for language editing.

Author contributions LG, JGa and JGr conceived the ideas and designed the experiments. LG conducted the experiments, analyzed the data and wrote the manuscript, which was revisited and edited by $\mathrm{JGa}$ and JGr. JGr supervised the project.

Funding Open Access funding enabled and organized by Projekt DEAL. L. Görg was supported by funds of the Federal Ministry of Food and Agriculture (BMEL) based on a decision of the Parliament of the Federal Republic of Germany via the Federal Office for Agriculture and Food (BLE) under the innovation support program number 2814900515 . J. Gallinger was supported by a fund of the "Landwirtschaftliche Rentenbank" number 28RF4IP008.

\section{Compliance with ethical standards}

Conflict of interest The authors declare that they have no conflict of interest.

Open Access This article is licensed under a Creative Commons Attribution 4.0 International License, which permits use, sharing, adaptation, distribution and reproduction in any medium or format, as long as you give appropriate credit to the original author(s) and the source, provide a link to the Creative Commons licence, and indicate if changes were made. The images or other third party material in this article are included in the article's Creative Commons licence, unless indicated otherwise in a credit line to the material. If material is not included in the article's Creative Commons licence and your intended use is not permitted by statutory regulation or exceeds the permitted use, you will need to obtain permission directly from the copyright holder. To view a copy of this licence, visit http://creativecommons.org/licenses/by/4.0/.

\section{References}

Ashford DA, Smith WA, Douglas AE (2000) Living on a high sugar diet: the fate of sucrose ingested by a phloem-feeding insect, the pea aphid Acyrthosiphon pisum. J Insect Physiol 46:335-341 
Bendix C, Lewis JD (2018) The enemy within: phloem-limited pathogens. Mol Plant Pathol 19(1):238-254

Bieleski RL (1969) Accumulation and translocation of sorbitol in apple phloem. Austr J Biol Sci 22:611-620

Bovey R (1961) Apple proliferation disease. Stations fédérales d'essais agricoles, Lausanne

Braun EJ, Sinclair WA (1978) Translocation in phloem necrosis-diseased American elm seedlings. Phytopathology 68:1733-1737

Bush DR (1992) The proton-sucrose symport. Photosyn Res 32:155165. https://doi.org/10.1007/BF00034792

Cao H-H, Wang S-H, Liu T-X (2014) Jasmonate-and salicylate-induced defenses in wheat affect host preference and probing behavior but not performance of the grain aphid, Sitobion avenae. Insect science 21:47-55

Carraro L, Osler R, Refatti E, Poggi PC (1988) Transmission of the possible agent of apple proliferation to Vinca rosea by dodder. Riv Patol Veget 1988:43-52

Carraro L, Ferrini F, Ermacora P, Loi N, Labonne G (2008) Infectivity of Cacopsylla picta (Syn. C. costalis), vector of 'Candidatus Phytoplasma mali' in North East Italy. Acta Hortic 781:403-408. https://doi.org/10.17660/ActaHortic.2008.781.57

Ciccotti AM, Bianchedi P, Bragagna P, Deromedi M, Filippi M, Forno F, Mattedi L (2008) Natural and experimental transmission of Candidatus Phytoplasma mali by root bridges. Acta Hortic 781:459-464

Crawley MJ (2012) The R book. Wiley, Hoboken, pp 449-497

de Marco F, Pagliari L, Degola F, Buxa SV, Loschi A, Dinant S, Le Hir R, Morin H, Santi S, Musetti R (2016) Combined microscopy and molecular analyses show phloem occlusions and cell wall modifications in tomato leaves in response to 'Candidatus Phytoplasma solani'. J Microsc 263:212-225. https://doi.org/10.1111/ jmi.12426

Dermastia M (2019) Plant hormones in phytoplasma infected plants. Front Plant Sci 10:477. https://doi.org/10.3389/fpls.2019.00477

Dicke M (2000) Chemical ecology of host-plant selection by herbivorous arthropods: a multitrophic perspective. Biochem Syst Ecol 28:601-617

Douglas AE (1998) Nutritional interactions in insect-microbial symbioses: aphids and their symbiotic bacteria Buchnera. Annu Rev Entomol 43:17-37. https://doi.org/10.1146/annurev.ento.43.1.17

Douglas AE (2006) Phloem-sap feeding by animals: problems and solutions. J Exp Bot 57:747-754. https://doi.org/10.1093/jxb/ erj067

Doyle JJ, Doyle JL (1990) Isolation of plant DNA from fresh tissue. Focus 12:13-15

Eben A, Gross J (2013) Innovative control of psyllid vectors of European fruit tree phytoplasmas. Phytopathogenic Mollicutes 3:37-39

Eigenbrode SD, Bosque-Pérez NA, Davis TS (2018) Insect-borne plant pathogens and their vectors: ecology, evolution, and complex interactions. Annu Rev Entomol 63:169-191

Fereres A, Moreno A (2009) Behavioural aspects influencing plant virus transmission by homopteran insects. Virus Res 141:158-168

Fontellas TML, Zucoloto FS (2003) Effect of sucrose ingestion on the performance of wild Anastrepha obliqua (Macquart) females (Diptera: Tephritidae). Neotrop Entomol 32:209-216. https://doi. org/10.1590/S1519-566X2003000200004

Frisinghelli C, Delaiti L, Grando MS, Forti D, Vindimian ME (2000) Cacopsylla costalis (Flor 1861), as a vector of apple proliferation in Trentino. J Phytopathol 148:425-431

Gai Y-P, Han X-J, Li Y-Q, Yuan C-Z, Mo Y-Y, Guo F-Y, Xian-Ling J (2014) Metabolomic analysis reveals the potential metabolites and pathogenesis involved in mulberry yellow dwarf disease. Plant Cell Environ 37:1474-1490
Galdeano DM, de Souza Pacheco I, Alves GR, Granato LM, Rashidi M, Turner D, Levy A, Machado MA (2020) Friend or foe? Relationship between 'Candidatus Liberibacter asiaticus' and Diaphorina citri. Trop Plant Pathol. https://doi.org/10.1007/s4085 8-020-00375-4

Gallinger J, Gross J (2018) Unraveling the host plant alternation of Cacopsylla pruni-adults but not nymphs can survive on conifers due to phloem/xylem composition. Front Plant Sci 9:484. https ://doi.org/10.3389/fpls.2018.00484

Gallinger J, Gross J (2020) Phloem metabolites of Prunus sp. rather than infection with Candidatus phytoplasma prunorum influence feeding behavior of Cacopsylla pruni nymphs. J Chem Ecol 2020:1-15. https://doi.org/10.1007/s10886-020-01148-8

Giorno F, Guerriero G, Biagetti M, Ciccotti AM, Baric S (2013) Gene expression and biochemical changes of carbohydrate metabolism in in vitro micro-propagated apple plantlets infected by ' $\mathrm{Candi}$ datus Phytoplasma mali’. Plant Physiol Biochem 70:311-317. https://doi.org/10.1016/j.plaphy.2013.05.040

Grafton-Cardwell EE, Stelinski LL, Stansly PA (2013) Biology and management of Asian citrus psyllid, vector of the huanglongbing pathogens. Annu Rev Entomol 58:413-432

Gross J (2013) Drugs for Bugs: The Potential of Infochemicals Mediating Insect-Plant-Microbe Interactions for Plant Protection and Medicine. In: Gang DR (ed) Phytochemicals, plant growth, and the environment. Springer, Berlin, pp 79-93

Gross J (2016) Chemical communication between phytopathogens, their host plants and vector insects and eavesdropping by natural enemies. Front Ecol Evol 4:104. https://doi.org/10.3389/ fevo.2016.00104

Gross J, Gündermann G (2016) Principles of IPM in cultivated crops and implementation of innovative strategies for sustainable plant protection. In: Horowitz AR, Ishaaya I (eds) Advances in insect control and resistance management. Springer, Berlin, pp 9-26

Gross J, Gallinger J, Rid M (2019a) Collection, identification and statistical analysis of volatile organic compound patterns emitted by phytoplasma infected plants. In Musetti R, Pagliari L (eds) Phytoplasmas: methods and protocols, methods in molecular biology, vol 1875. Springer, pp 333-343. https://doi. org/10.1007/978-1-4939-8837-2_25

Gross J, Czarnobai de Jorge B, Gallinger J, Görg L, Maurer D, Rid M (2019b) The chemistry of multitrophic interactions in phytoplasma disease systems and advances in control of psyllid vectors with semiochemicals. Phytopathogenic Mollicutes 9:157-158

Hewer A, Will T, van Bel AJE (2010) Plant cues for aphid navigation in vascular tissues. J Exp Biol 213:4030-4042. https://doi. org/10.1242/jeb.046326

Hijaz F, Killiny N (2014) Collection and chemical composition of phloem sap from Citrus sinensis L. Osbeck (sweet orange). PLoS ONE 9:e101830. https://doi.org/10.1371/journal.pone.0101830

Hogenhout SA, Oshima K, Ammar E-D, Kakizawa S, Kingdom HN, Namba S (2008) Phytoplasmas: bacteria that manipulate plants and insects. Mol Plant Pathol 9:403-423

IRPCM Phytoplasma/Spiroplasma Working Team-Phytoplasma Taxonomy Group (2004) 'Candidatus Phytoplasma', a taxon for the wall-less, non-helical prokaryotes that colonize plant phloem and insects. Int J Syst Evol Microbiol 54:1243-1255

Jaenike J (1978) On optimal oviposition behavior in phytophagous insects. Theor Popul Biol 14:350-356

Janik K, Mithöfer A, Raffeiner M, Stellmach H, Hause B, Schlink K (2017) An effector of apple proliferation phytoplasma targets TCP transcription factors-a generalized virulence strategy of phytoplasma? Mol Plant Pathol 18:435-442. https://doi. org/10.1111/mpp.12409

Jarausch B, Schwind N, Jarausch W, Krczal G, Dickler E, Seemüller E (2003) First report of Cacopsylla picta as a vector of apple 
proliferation phytoplasma in Germany. Plant Dis 87:101. https ://doi.org/10.1094/PDIS.2003.87.1.101A

Jarausch B, Schwind N, Jarausch W, Krczal G (2004) Overwintering adults and springtime generation of Cacopsylla picta (Synonym C. costalis) can transmit apple proliferation phytoplasma. Acta Hortic 2004:409-413. https://doi.org/10.17660/ActaHortic .2004 .657 .65

Jarausch B, Fuchs A, König D, Krczal G, Jarausch W (2010) Analysis of the acquisition and multiplication eiciency of different strains of Ca. Phytoplasma mali by the vector Cacopsylla picta. JuliusKühn-Archiv 427:175-177

Jarausch B, Schwind N, Fuchs A, Jarausch W (2011) Characteristics of the spread of apple proliferation by its vector Cacopsylla picta. Phytopathology 101:1471-1480

Jarausch B, Sauvion N, Jarausch W (2013) Spread of European fruit tree phytoplasma diseases. Phytopathogenic Mollicutes 3:25-30

Jarausch B, Tedeschi R, Sauvion N, Gross J, Jarausch W (2019) Psyllid vectors. In: Bertaccini A, Weintraub PG, Rao GP, Mori N (eds) Phytoplasmas: plant pathogenic bacteria-II, vol 92. Springer, Singapore, pp 53-78

Kallenbach M, Bonaventure G, Gilardoni PA, Wissgott A, Baldwin IT (2012) Empoasca leafhoppers attack wild tobacco plants in a jasmonate-dependent manner and identify jasmonate mutants in natural populations. Proc Natl Acad Sci USA 109:E1548-E1557. https://doi.org/10.1073/pnas.1200363109

Kollar A, Seemüller E (1990) Chemical composition of phloem exudate of mycoplasma-infected apple trees. J Phytopathol 128:99111. https://doi.org/10.1111/j.1439-0434.1990.tb04256.x

Kube M, Schneider B, Kuhl H, Dandekar T, Heitmann K, Migdoll AM, Reinhardt R, Seemüller E (2008) The linear chromosome of the plant-pathogenic mycoplasma 'Candidatus Phytoplasma mali'. BMC Genomics 9:306. https://doi.org/10.1186/1471-2164-9-306

Kube M, Mitrovic J, Duduk B, Rabus R, Seemüller E (2012) Current view on phytoplasma genomes and encoded metabolism. Sci World J 2012:185942. https://doi.org/10.1100/2012/185942

Le Goff GJ, Lebbe O, Lohaus G, Richels A, Jacquet N, Byttebier V, Hance T (2019) What are the nutritional needs of the pear psylla Cacopsylla pyri? Arthropod-Plant Interactions 13:431-439. https ://doi.org/10.1007/s11829-018-9644-7

Lee I-M, Davis RE, Gundersen-Rindal DE (2000) Phytoplasma: phytopathogenic mollicutes. Annu Rev Microbiol 54:221-255

Lenth R, Singmann H, Love J, Buerkner P, Herve M (2019) emmeans: estimated marginal means. Depends: R ( $\geq 3.2)$. https://githu b.com/rvlenth/emmeans. Accessed 19 July 2020

Lepka P (1999) Effect of phytoplasmal infection on concentration and translocation of carbohydrates and amino acids in periwinkle and tobacco. Physiol Mol Plant Pathol 551(1999):59-68

Loescher WH (1987) Physiology and metabolism of sugar alcohols in higher plants. Physiol Plant 70:553-557

Lorenz K-H, Schneider B, Ahrens U, Seemüller E (1995) Detection of the apple proliferation and pear decline phytoplasmas by PCR amplification of ribosomal and nonribosomal DNA. Phytopathology 85:771-776

Malagnini V, Pedrazzoli F, Gualandri V, Forno F, Zasso R, Pozzebon A, Ioriatti C (2010) A study of the effects of 'Candidatus Phytoplasma mali' on the psyllid Cacopsylla melanoneura (Hemiptera: Psyllidae). J Invertebr Pathol 103:65-67

Mattedi L, Forno F, Cainelli C, Grando MS, Jarausch W (2008) Research on Candidatus Phytoplasma mali transmission by insect vectors in Trentino. Acta Hortic 2008:369-374. https:// doi.org/10.17660/ActaHortic.2008.781.52

Mauck KE, de Moraes CM, Mescher MC (2016) Effects of pathogens on sensory-mediated interactions between plants and insect vectors. Curr Opin Plant Biol 32:53-61
Maust BE, Espadas F, Talavera C, Aguilar M, Santamaría JM, Oropeza C (2003) Changes in carbohydrate metabolism in coconut palms infected with the lethal yellowing phytoplasma. Phytopathology 93:976-981

Mayer CJ, Gross J (2007) Different host plant odours influence migration behaviour of Cacopsylla melanoneura (Forster), an insect vector of the apple proliferation phytoplasma. IOBC WPRS Bull 30:177

Mayer CJ, Vilcinskas A, Gross J (2008a) b) Pathogen-induced release of plant allomone manipulates vector insect behavior. J Chem Ecol 34:1518-1522. https://doi.org/10.1007/s10886-008-9564-6

Mayer CJ, Vilcinskas A, Gross J (2008b) a) Phytopathogen lures its insect vector by altering host plant odor. J Chem Ecol 34:10451049. https://doi.org/10.1007/s10886-008-9516-1

Mayer CJ, Jarausch B, Jarausch W, Jelkmann W, Vilcinskas A, Gross J (2009) Cacopsylla melanoneura has no relevance as vector of apple proliferation in Germany. Phytopathology 99:729-738

Mayer CJ, Vilcinskas A, Gross J (2011) Chemically mediated multitrophic interactions in a plant-insect vector-phytoplasma system compared with a partially nonvector species. Agric For Entomol 13:25-35. https://doi.org/10.1111/j.1461-9563.2010.00495.x

Meier U, Graf H, Hack H, Hess M, Kennel W, Klose R, Mappes D, Seipp D, Stauss R, Streif J (1994) Phänologische Entwicklungsstadien des Kernobstes (Malus domestica Borkh. und Pyrus communis L.), des Steinobstes (Prunus-Arten), der Johannisbeere Ribes-Arten) und der Erdbeere (Fragaria x ananassa Duch.). Nachrichtenblatt Deutschen Pflanzenschutzdienstes 46:141-153

Minchin PEH, Lacointe A (2005) New understanding on phloem physiology and possible consequences for modelling long-distance carbon transport. New Phytol 166:771-779. https://doi.org/10. 1111/j.1469-8137.2005.01323.x

Mittler TE, Dadd RH (1963) Studies on the artificial feeding of the aphid Myzus persicae (Sulzer) - I. Relative uptake of water and sucrose solutions. J Insect Physiol 9:623-645. https://doi. org/10.1016/0022-1910(63)90008-8

Musetti R, Paolacci A, Ciaffi M, Tanzarella OA, Polizzotto R, Tubaro F, Mizzau M, Ermacora P, Badiani M, Osler R (2010) Phloem cytochemical modification and gene expression following the recovery of apple plants from apple proliferation disease. Phytopathology 100:390-399. https://doi.org/10.1094/PHYTO $-100-4-0390$

Musetti R, Farhan K, de Marco F, Polizzotto R, Paolacci A, Ciaffi M, Ermacora P, Grisan S, Santi S, Osler R (2013) Differentiallyregulated defence genes in Malus domestica during phytoplasma infection and recovery. Eur J Plant Pathol 136:13-19. https://doi. org/10.1007/s10658-012-0147-6

Müther J, Vogt H (2003) Sampling methods in orchard trials: a comparison between beating and inventory sampling. IOBC WPRS Bull 26:67-72

Oksanen J, Kindt R, Simpson GL (2018) vegan3d: static and dynamic 3D Plots for the 'vegan' Package. Depends: $R(\geq 3.2 .0)$, vegan ( $\geq 2.3-0)$. https://cran.r-project.org/web/packages/vegan3d/index .html. Accessed 19 July 2020

Oksanen J, Blanchet FG, Friendly M, Kindt R, Legendre P, McGlinn D, Minchin PR, O'Hara RB, Simpson GL, Solymos P, Stevens MHH, Szoecs E, Wagner H (2019) vegan: community ecology package. https://cran.r-project.org/web/packages/vegan/index .html. Accessed 19 July 2020

Oppedisano T, Panassiti B, Pedrazzoli F, Mittelberger C, Bianchedi P, Angeli G, de Cristofaro A, Janik K, Anfora G, Ioriatti C (2020) Importance of psyllids' life stage in the epidemiology of apple proliferation phytoplasma. J Pest Sci 93:49-61

Orlovskis Z, Canale MC, Thole V, Pecher P, Lopes JR, Hogenhout SA (2015) Insect-borne plant pathogenic bacteria: getting a ride goes 
beyond physical contact. Curr Opin Insect Sci 9:16-23. https:// doi.org/10.1016/j.cois.2015.04.007

Oshima K, Kakizawa S, Nishigawa H, Jung H-Y, Wei W, Suzuki S, Arashida R, Nakata D, Miyata S-i, Ugaki M, Namba S (2004) Reductive evolution suggested from the complete genome sequence of a plant-pathogenic phytoplasma. Nat Genet 36:2729. https://doi.org/10.1038/ng 1277

Ossiannilsson F (1992) The Psylloidea (Homoptera) of Fennoscandia and Denmark. Fauna Entomologica Scandinavica, vol 26. Brill, Leiden

Pedrazzoli F, Gualandri V, Forno F, Mattedi L, Malagnini V, Salvadori A, Stoppa G, Ioriatti C (2007) Acquisition capacities of the overwintering adults of the psyllid vectors of Candidatus Phytoplasma mali. Bull Insectol 60(2):195-196

Pedrazzoli F, Ciccotti AM, Bianchedi P, Salvadori A, Zorer R (2008) Seasonal colonisation behaviour of Candidatus Phytoplasma mali in apple trees in Trentino. Acta Hortic 2008:483-488

Perilla-Henao LM, Casteel CL (2016) Vector-borne bacterial plant pathogens: interactions with hemipteran insects and plants. Front Plant Sci 7:1163

Powell G, Tosh CR, Hardie J (2006) Host plant selection by aphids: behavioral, evolutionary, and applied perspectives. Annu Rev Entomol 51:309-330

Pradit N, Mescher MC, de Moraes CM, Wang Y, Vorsa N, RodriguezSaona C (2019) Phytoplasma infection of cranberries benefits non-vector phytophagous insects. Front Ecol Evol 7:181

Prokopy RJ, Owens ED (1978) Visual generalist with visual specialist phytophagous insects: host selection behaviour and application to management. Entomol Exp Appl 24:609-620

Ranger CM, Johnson-Cicalese J, Polavarapu S, Vorsa N (2006) Evaluation of Vaccinium spp. for Illinoia pepperi (Hemiptera: Aphididae) performance and phenolic content. J Econ Entomol 99(4):1474-1482

Reidel EJ, Rennie EA, Amiard V, Cheng L, Turgeon R (2009) Phloem loading strategies in three plant species that transport sugar alcohols. Plant Physiol 149:1601-1608. https://doi.org/10.1104/ pp.108.134791

Rid M, Mesca C, Ayasse M, Gross J (2016) Apple proliferation phytoplasma influences the pattern of plant volatiles emitted depending on pathogen virulence. Front Ecol Evol 3:152

Ripley B, Venables B, Bates DM, Hornik K, Gebhardt A, Firth D (2019) MASS: Support Functions and Datasets for Venables and Ripley's MASS. Depends: R ( $\geq 3.1 .0)$. https://cran.r-project.org/ web/packages/MASS/index.html

Rosa M, Prado C, Podazza G, Interdonato R, González JA, Hilal M, Prado FE (2009) Soluble sugars-metabolism, sensing and abiotic stress: a complex network in the life of plants. Plant Signal Behav 4:388-393. https://doi.org/10.4161/psb.4.5.8294

RStudio Team (2019) RStudio: Integrated Development for R: "Orange Blossom” (330255dd, 2019-12-04). R Studio, Inc., Boston, MA. https://www.rstudio.com/

Schaper U, Seemüller E (1982) Condition of the phloem and the persistence of mycoplasma like organisms associated with apple proliferation and pear decline. Phytopathology 72:736-742

Schaper U, Seemüller E (1984) Recolonization of the stem of apple proliferation and pear decline-diseased trees by the causal organisms in spring/Wiederbesiedlung des Sprosses von triebsuchtkranken Apfelbäumen und verfallskranken Birnbäumen durch die Erreger im Frühjahr. J Plant Dis Protect 1984:608-613

Schoonhoven LM, van Loon B, van Loon JJA, Dicke M (2005) Insectplant biology. Oxford University Press, Oxford

Seemüller E, Schneider B (2004) 'Candidatus Phytoplasma mali', 'Candidatus Phytoplasma pyri' and 'Candidatus Phytoplasma prunorum', the causal agents of apple proliferation, pear decline and European stone fruit yellows, respectively. Int J Syst Evol Microbiol 54:1217-1226
Seemüller E, Marcone C, Lauer U, Ragozzino A, Göschl M (1998) Current status of molecular classification of the phytoplasmas. J Plant Pathol 1998:3-26

Seemüller E, Kiss E, Sule S, Schneider B (2010) Multiple infection of apple trees by distinct strains of 'Candidatus Phytoplasma mali' and its pathological relevance. Phytopathology 100:863-870

Seemüller E, Carraro L, Jarausch W, Schneider B (eds) (2011) Apple proliferation phytoplasma. Virus and Virus-Like Diseases of Pome and Stones Fruits. American Phytopathological Society

Seemüller E, Sule S, Kube M, Jelkmann W, Schneider B (2013) The $\mathrm{AAA}+\mathrm{ATPases}$ and $\mathrm{HflB} / \mathrm{FtsH}$ proteases of 'Candidatus Phytoplasma mali': phylogenetic diversity, membrane topology, and relationship to strain virulence. Mol Plant Microbe Interact 26:367-376. https://doi.org/10.1094/MPMI-09-12-0221-R

Setamou M, Simpson CR, Alabi OJ, Nelson SD, Telagamsetty S, Jifon JL (2016) Quality matters: influences of citrus flush physicochemical characteristics on population dynamics of the Asian citrus psyllid (Hemiptera: Liviidae). PLoS ONE 2016:11

Shikano I, Rosa C, Tan C-W, Felton GW (2017) Tritrophic interactions: microbe-mediated plant effects on insect herbivores. Annu Rev of Phytopathol 55:313-331

Siewert C, Luge T, Duduk B, Seemüller E, Büttner C, Sauer S, Kube M (2014) Analysis of expressed genes of the bacterium 'Candidatus phytoplasma Mali' highlights key features of virulence and metabolism. PLoS ONE 9:e94391. https://doi.org/10.1371/ journal.pone.0094391

Singer MC, Vasco D, Parmesan C, Thomas CD, Ng D (1992) Distinguishing between 'preference' and 'motivation' in food choice: an example from insect oviposition. Anim Behav 44:463-471

Steinbauer MJ (2013) Shoot feeding as a nutrient acquisition strategy in free-living psylloids. PLoS ONE 8(10):e77990

Steinbauer MJ, Farnier K, Taylor GS, Salminen J-P (2016) Effects of eucalypt nutritional quality on the Bog gum-Victorian metapopulation of Ctenarytaina bipartita and implications for host and range expansion. Ecol Entomol 41(2):211-225

Stout MJ, Thaler JS, Thomma BP (2006) Plant-mediated interactions between pathogenic microorganisms and herbivorous arthropods. Annu Rev Entomol 51:663-689

Strauss E (2009) Phytoplasma research begins to bloom. Science 325(5939):388-390. https://doi.org/10.1126/science.325_388

Sugio A, Kingdom HN, MacLean AM, Grieve VM, Hogenhout SA (2011) Phytoplasma protein effector SAP11 enhances insect vector reproduction by manipulating plant development and defense hormone biosynthesis. Proc Natl Acad Sci USA 108:E1254E1263. https://doi.org/10.1073/pnas.1105664108

Tamborindeguy C, Huot OB, Ibanez F, Levy J (2017) The influence of bacteria on multitrophic interactions among plants, psyllids, and pathogen. Insect Sci 24(6):961-974

Tedeschi R, Bosco D, Alma A (2002) Population dynamics of Cacopsylla melanoneura (Homoptera: Psyllidae), a vector of apple proliferation phytoplasma in northwestern Italy. J Econ Entomol 95:544-551

Thao ML, Moran NA, Abbot P, Brennan EB, Burckhardt DH, Baumann $\mathrm{P}$ (2000) Cospeciation of psyllids and their primary prokaryotic endosymbionts. Appl Environ Microbiol 66:2898-2905

Turgeon R (1989) The sink-source transition in leaves. Annu Rev Plant Biol 40:119-138

van Bel AJE (2003) The phloem, a miracle of ingenuity. Plant Cell Environ 26:125-149. https://doi.org/10.104 6/j.1365-3040.2003.00963.x

Villas-Bôas SG, Smart KF, Sivakumaran S, Lane GA (2011) Alkylation or silylation for analysis of amino and non-amino organic acids by GC-MS? Metabolites 1:3-20. https://doi.org/10.3390/ metabo1010003

Weintraub PG, Beanland L (2006) Insect vectors of phytoplasmas. Annu Rev Entomol 51:91-111 
Wickham H, Chang W, Henry L, Pedersen TL, Takahashi K, Wilke C, Woo K, Yutani H, RStudio (2019) ggplot2: Elegant Graphics for Data Analysis. Depends: R ( $\geq 3.2)$, New York. https://ggplo t2.tidyverse.org

Will T, Furch ACU, Zimmermann MR (2013) How phloem-feeding insects face the challenge of phloem-located defenses. Front Plant Sci 4:336. https://doi.org/10.3389/fpls.2013.00336
Zimmermann MR, Schneider B, Mithöfer A, Reichelt M, Seemüller E, Furch ACU (2015) Implications of Candidatus Phytoplasma mali infection on phloem function of apple trees Endocytobiosis and cell research. J Int Soc Endocytobiol 26:67-75

Zuur AF, Ieno EN, Walker N, Saveliev AA, Smith GM (2009) Mixed effects models and extensions in ecology with R. Springer Science \& Business Media, Berlin 